\title{
Benefits from Organic Fertilizer by Wheat (Triticum aestivum) and Faba Bean (Vicia faba) Under Intercropping System in Western Shoa, Ethiopia
}

\begin{abstract}
Fikadu Kumsa
Department of Biology, College of Natural and Computational Science, Ambo University, Ethiopia.

Abstract: Manure is a best many nutrients supply for crop production. It also considered as valuable sources for increasing soil organic matter content and improving soil structure. The cropping systems were composed of sole wheat, sole faba bean, and alternate at two locations. The treatments were formed from different

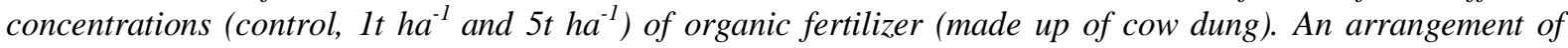
cropping systems with different concentrations of organic fertilizers has been proved to have an effect on yield and growth parameters of both wheat and faba bean. The maximum yield of wheat were recorded when $5 t$ ha ${ }^{1}$ organic fertilizer was applied to alternate cropped system. While, maximum yield of faba bean $\left(2000 \mathrm{Kg} \mathrm{ha}{ }^{-1}\right)$ were obtained when it were sown alone at $5 t \mathrm{ha}^{-1}$ organic fertilizer. Even though all cropped system has been shown a better yield at high concentrations of organic fertilizer, intercropped systems did contributing in the production of the highest yield of wheat at both sites. From the obtained result, it can be concluded that, as concentration of organic fertilizer increased, there is an increment of yields among both cultivars at both Guder and Ginchi sites. But, the best yields of wheat were obtained from alternative intercropping at highest tested organic fertilizer at both sites. The tested level of organic fertilizer and cropping systems approach has very much useful as it increase the yield.
\end{abstract}

Keywords: Organic fertilizer, Biomass, Cropping System, Faba bean, Tiller, Yield.

\section{INTRODUCTION}

Manure is a best many nutrients supply for crop production. It also considered as valuable sources for increasing soil organic matter content and improving soil structure. Moreover, compost has a high nutritional value, with high concentrations of especially nitrogen, phosphorus and potassium (Tayebeh Abedi et al, 2010). The wise use of this integrated nutrient can contribute for sustainable agricultural productivity through enhancing plant growth, water, and soil and land management. Thus, integrated soil nutrient management was increased the crop yield. According to Zahoor (2014), farmyard manures have a high potential to boost up crop productivity in terms of yield and yield components when combined with chemical fertilizer. Study done on effect of bio-fertilizer when supplied to wheat along with recommended dose of N-P-K fertilizers showed that, a significant influence on plant height, number of tillers plant, spike length, and grain yield.

There is a need to increase the yield of cereal crops to achieve an integrated farming to fulfill its demands resulted from the world population. This, yield increment can be obtained from using organic fertilizers or developing a cropping systems such as intercropping. Previous report had shown that the sheep manure, cow manure and poultry manure were contributed for better yield production of wheat (Ahmed Mam Rasul et al, 2015). Wheat is one of the most important crops which play a major role to solve food insufficient problem (Muhammed et al., 2013).

Faba bean is grown world-wide as protein source for food and feed, but at the same time faba bean offers ecosystem services such as renewable inputs of nitrogen $(\mathrm{N})$ into crops and soil via biological $\mathrm{N}_{2}$ fixation, and a diversification of cropping systems (Jensen et al 2010). According to Eskandari and Ghanbari (2010), intercropping is important practice for the development of sustainable food as it has a potential benefits for high productivity and profitability, improvement of soil fertility through the addition of nitrogen and efficient use of environmental resources through the complementary effects of two or more crops. The aim of this study was to evaluate the effect of organic fertilizer on yield and yield components of inter-cropped wheat and faba bean. 


\section{MATerials AND Methods}

\subsection{Description of the Study Area}

The field experiments were carried out in western Shoa at Ginchi and Guder during main cropping season of 2012-2013. The study sites were located in West Shoa zone of Oromia National Regional State, central Ethiopia. Ginchi research site is located at $85 \mathrm{~km}$ West of Addis Ababa while, Guder Production Farm is located at $124 \mathrm{~km}$, West of Addis Ababa at an altitude of 2200 and 1800 above mean sea level, respectively. The soil type of Ginchi research site is Vertisols with pH of 6.5 at soil depth of 0 to $30 \mathrm{~cm}$. Slope of the study site is ranges from 2 to $5 \%$. On the other hand, the soil type of Guder Production Farm is Nitosol with soil pH of 5.5 to 6.0 at similar soil depth. Both study areas have a unimodal rainfall pattern and average annual total rainfall ranging between $800-1260 \mathrm{~mm}$. The annual (2012-2013) mean minimum, maximum and average air temperatures are 8.91, 25.0 and 18.37 ${ }^{0} \mathrm{C}$, respectively.

\subsection{Experimental Design and Treatments}

The experiments were laid out in a randomized complete block designs (RCBD) with three replications. The cropping systems were composed of sole wheat, sole faba bean, and alternate at two locations. The treatments were formed from different concentrations (control, $1 \mathrm{t} \mathrm{ha}^{-1}$ and $5 \mathrm{t} \mathrm{ha}^{-1}$ ) of organic fertilizer (made up of cow dung). All agronomic practices were undertaken. The improved wheat variety and Faba bean were sown in drill at a seed rate of $175 \mathrm{~kg} \mathrm{ha}^{-1}$ and $200 \mathrm{~kg} \mathrm{ha}^{-1}$, respectively (Getachewet al., 2008). Detailed information of yield-crop spatial arrangements relationship during intercropping were investigated and recorded.

\subsection{Data Collection and Analysis}

The collected data includes plant height, dry biomass, number of tillers and grain yield. Collected data were subjected to analysis of variance (ANOVA). Treatments and mean differences were separated by the least significant difference (LSD) test at 0.05 probability level. All statistical analyses were performed using the SPSS version 16.0 statistical software.

\section{RESULTS AND DISCUSSIONS}

\subsection{Effect of Organic Fertilizer on Cropping Systems, Yield and Other Growth Parameters at Guder Site}

Different concentrations of organic fertilizers $\left(0,1\right.$, and $\left.5 \mathrm{t} \mathrm{ha}^{-1}\right)$ were used to determine the yield and other growth parameters among cropping systems. Accordingly, the maximum yield of wheat were recorded when $5 \mathrm{t} \mathrm{ha}^{-1}$ organic fertilizer was applied to alternate cropped system. While, maximum yield of faba bean $\left(2000 \mathrm{Kg} \mathrm{ha}^{-1}\right)$ were obtained when it were sown alone at $5 \mathrm{tha}^{-1}$ organic fertilizer. From the different intercropped systems tested at Guder site, the maximum wheat dry biomass $\left(3858 \mathrm{Kg} \mathrm{ha}^{-1}\right)$, tiller number $(6.3)$ and spike length $(8 \mathrm{~cm})$ were obtained during alternatively intercropped. But the capacity of wheat to induce yield was reduced when sown alone $\left(800 \mathrm{Kg} \mathrm{ha}^{-1}\right)$ at absence of organic fertilizer. An increment of yield was also recorded when 1 tha $^{-1}$ organic fertilizer were applied to alone cropped system for both cultivars. The minimum faba bean yield was obtained from alternate intercropped $\left(1075 \mathrm{Kg} \mathrm{ha}^{-1}\right)$ at absence of organic fertilizer. Wheat plants were shortest in the sole plot $(103 \mathrm{~cm})$. But the height of wheat increased in faba bean population in alternate (109 $\mathrm{cm})$ intercropped. This result revealed that, application of organic fertilizer to alternate intercropped wheat with faba bean was effective in yield at Guder site (LER>2) (table 1).

Table 1. Organic fertilizers on cropped systems, yield and other growth parameters at Guder site

\begin{tabular}{|c|c|c|c|c|c|c|c|}
\hline $\begin{array}{l}\text { Cropping } \\
\text { systems }\end{array}$ & $\begin{array}{l}\text { Organic fertilizer }(t) \\
\left.\text { ha }^{-1}\right)\end{array}$ & $\begin{array}{l}\text { Yield } \\
\left(\mathrm{Kg} \mathrm{ha}^{-1}\right)\end{array}$ & $\begin{array}{l}\text { Dry Biomass } \\
\left(\mathbf{K g ~ h a}^{-1}\right)\end{array}$ & $\begin{array}{l}\text { Height } \\
(\mathrm{cm})\end{array}$ & $\begin{array}{l}\text { Tiller } \\
\text { No }\end{array}$ & $\begin{array}{l}\begin{array}{l}\text { Spike length } \\
\text { (cm) }\end{array} \\
\end{array}$ & LER \\
\hline \multirow{3}{*}{$\begin{array}{l}\text { 1. Sole } \\
\text { Wheat }\end{array}$} & 0 & $800.6 \mathrm{~d}$ & $1697.5 \mathrm{~d}$ & $103 c$ & $3.7 b$ & $6.4 \mathrm{bc}$ & \\
\hline & 1 & $1350 \mathrm{c}$ & $2515 c$ & $105 \mathrm{c}$ & $3.8 \mathrm{~b}$ & $6.5 \mathrm{~b}$ & \\
\hline & 5 & $1700 \mathrm{ab}$ & $3200 \mathrm{a}$ & $107 \mathrm{~b}$ & $3.8 \mathrm{~b}$ & $6.0 \mathrm{c}$ & \\
\hline \multirow{3}{*}{$\begin{array}{l}\text { 2. Sole Faba } \\
\text { Bean }\end{array}$} & 0 & $1000 \mathrm{c}$ & $1930.8 \mathrm{~d}$ & $134 \mathrm{a}$ & $4.8 \mathrm{a}$ & & \\
\hline & 1 & $1500 \mathrm{~b}$ & $2955 b$ & $135 \mathrm{a}$ & $4.9 \mathrm{a}$ & & \\
\hline & 5 & $1820 \mathrm{a}$ & $3490 a$ & $135 \mathrm{a}$ & $5.0 \mathrm{a}$ & & \\
\hline \multirow[t]{2}{*}{$\begin{array}{l}\text { 3. Alternate } \\
\text { intercropped }\end{array}$} & & & & & & & \\
\hline & 0 & $1520.8 \mathrm{~b}$ & $2968.3 b$ & $109 \mathrm{~b}$ & $6.1 \mathrm{a}$ & $7.4 \mathrm{~b}$ & 2.22 \\
\hline \multirow[t]{2}{*}{ Wheat } & 1 & $1700 \mathrm{ab}$ & $3350 \mathrm{a}$ & $108 \mathrm{~b}$ & $6.3 a$ & $7.6 \mathrm{a}$ & \\
\hline & 5 & $2000 a$ & $3858 \mathrm{a}$ & $109 \mathrm{~b}$ & $6.3 a$ & $8.0 \mathrm{a}$ & \\
\hline \multirow[b]{3}{*}{ Faba Bean } & 0 & $1075 \mathrm{c}$ & $1866.6 \mathrm{~d}$ & $130 \mathrm{a}$ & $2.8 \mathrm{~d}$ & & \\
\hline & 1 & $1501 b$ & $2980 b$ & $132 \mathrm{a}$ & $2.7 \mathrm{~d}$ & & \\
\hline & 5 & $1200 \mathrm{c}$ & $2300 \mathrm{c}$ & $134 a$ & $2.9 \mathrm{~d}$ & & \\
\hline
\end{tabular}


Benefits from Organic Fertilizer by Wheat (Triticum aestivum) and Faba Bean (Vicia faba) Under Intercropping System in Western Shoa, Ethiopia

The data present the mean number of yield and other growth parameters of the experiments. Means having the same letters in a column were not significantly different at $5 \%$ probability level.

During the first 45 days, well defined growth parameters were observed at all cropping systems except for a slight difference (Figure 1).

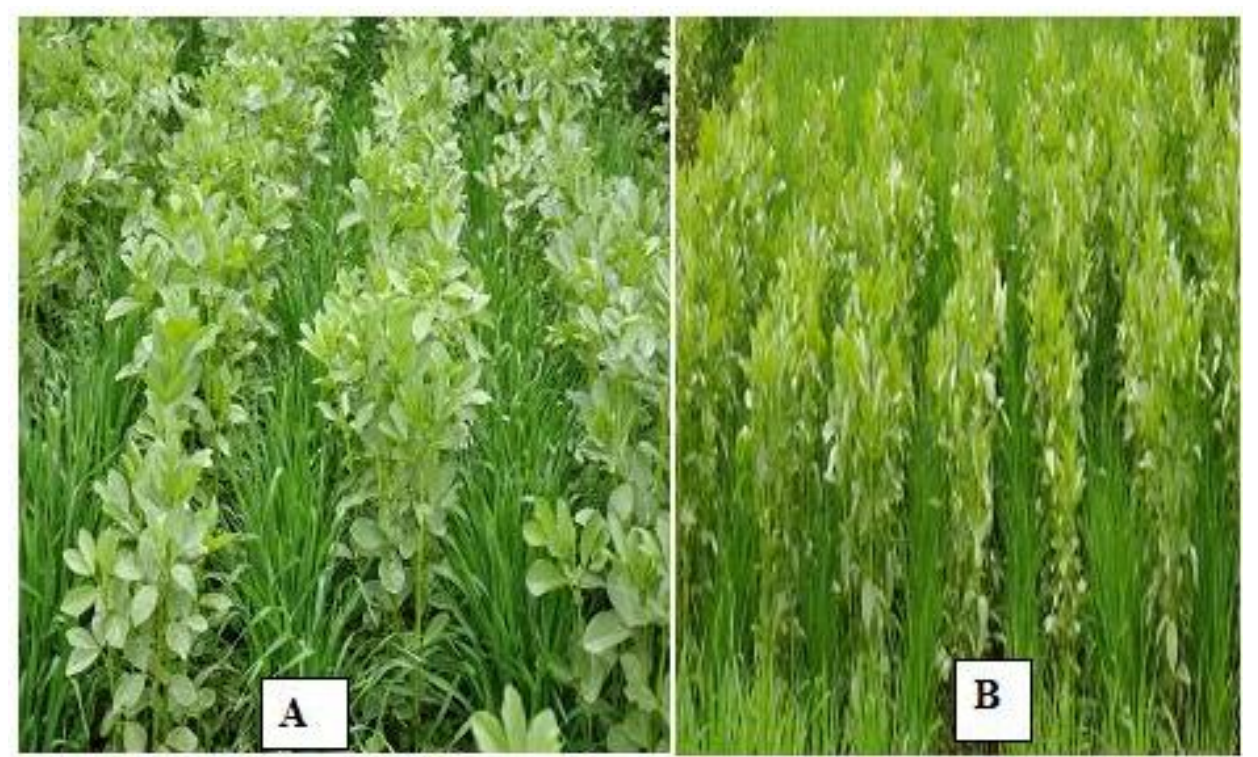

Figure 1.Application of organic fertilizers toalternate inter-cropped system of wheat with Faba bean at Guder site $(\boldsymbol{A}=$ Alternate intercropped treated at 5 t hat organic fertilizer, $\boldsymbol{B}=$ Alternate intercropped treated as control $)$ from 12 July to 27 August 2012).

\subsection{Effect of organic fertilizer on cropping systems, yield and other growth parameters at Ginchi site}

Like Guder, Ginchi site also produced the best yield of wheat $\left(1600 \mathrm{Kg} \mathrm{ha}^{-1}\right)$ once $5 \mathrm{t} \mathrm{ha}^{-1}$ organic fertilizer was applied to alternate intercropped system. Likewise, significant yield was obtained from sole cropped $\left(1500 \mathrm{Kg} \mathrm{ha}^{-1}\right)$ system of faba bean. The maximum biomasses $\left(3100 \mathrm{Kg} \mathrm{ha}^{-1}\right)$ and $(3000$ $\mathrm{Kg} \mathrm{ha}^{-1}$ ) were also obtained on alternate for wheat and sole cropped for faba bean treated at $5 \mathrm{t} \mathrm{ha}^{-1}$, respectively. Even though significant yield of faba bean was obtained from sole intercropped system at $5 \mathrm{t} \mathrm{ha}{ }^{-1}$ organic fertilizer, non-significant yields were obtained at alternate intercropped systems. A significantly different tiller number and spike length were also proved on alternate and sole cropped systems (Table 2). Even though, length of wheat cultivar in all cropping system was nearly the same at different treatments of organic fertilizers, sole faba bean has shown a significant length $(90 \mathrm{~cm})$ over sole) and alternate $(89 \mathrm{~cm})$ intercropped systems treated at $5 \mathrm{t} \mathrm{ha}^{-1}$ organic fertilizer (table 2 ).

Table 2.Organic fertilizers on cropped systems, yield and other growth parameters at Ginchi site

\begin{tabular}{|c|c|c|c|c|c|c|c|}
\hline $\begin{array}{l}\text { Cropping } \\
\text { systems }\end{array}$ & $\begin{array}{l}\text { Organic } \\
\text { fertilizer } \\
\left(\mathbf{t ~ h a}^{-1}\right)\end{array}$ & $\begin{array}{l}\text { Yield } \\
\left(\mathrm{Kg} \mathrm{ha}^{-1}\right)\end{array}$ & $\begin{array}{l}\text { Dry } \\
\text { Biomass } \\
\left(\mathrm{Kg} \mathrm{ha}^{-1}\right)\end{array}$ & $\begin{array}{l}\text { Height } \\
\text { (cm) }\end{array}$ & $\begin{array}{l}\text { Tiller } \\
\text { No }\end{array}$ & $\begin{array}{l}\text { Spike } \\
\text { length } \\
\text { (cm) }\end{array}$ & LER \\
\hline \multirow{3}{*}{ 1. Sole Wheat } & 0 & $790 \mathrm{~d}$ & $1478.3 \mathrm{c}$ & $83 d$ & $1.7 \mathrm{~d}$ & $5.2 \mathrm{c}$ & \\
\hline & 1 & $900 \mathrm{~d}$ & $1715 \mathrm{bc}$ & $87 \mathrm{c}$ & $2.5 \mathrm{c}$ & $5.6 \mathrm{~b}$ & \\
\hline & 5 & $1250 \mathrm{c}$ & $2310 b$ & $88 \mathrm{~b}$ & $3.0 \mathrm{~b}$ & $6.5 \mathrm{a}$ & \\
\hline \multirow{3}{*}{$\begin{array}{c}\text { 2.SoleFaba } \\
\text { Bean }\end{array}$} & 0 & $892.5 d$ & $1694.2 \mathrm{bc}$ & $88 \mathrm{~b}$ & 2.4 & 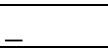 & \\
\hline & 1 & $945 d$ & $1790 b c$ & $87 \mathrm{c}$ & $3.0 \mathrm{~b}$ & & \\
\hline & 5 & $1500 \mathrm{~b}$ & $3000 a$ & $90 \mathrm{a}$ & $5.0 \mathrm{a}$ & & \\
\hline \multicolumn{8}{|l|}{$\begin{array}{l}\text { 3.Alternate } \\
\text { intercropped }\end{array}$} \\
\hline \multirow{3}{*}{ Wheat } & 0 & $1013 c$ & $1900.8 \mathrm{bc}$ & $85 d$ & $2.2 \mathrm{c}$ & $5.6 \mathrm{~b}$ & 2.3 \\
\hline & 1 & $1255 \mathrm{c}$ & $2300 \mathrm{~b}$ & $88 b$ & $3.0 \mathrm{~b}$ & $6.5 \mathrm{a}$ & \\
\hline & 5 & $1600 \mathrm{~b}$ & $3100 \mathrm{a}$ & $90 \mathrm{a}$ & $4.0 \mathrm{a}$ & $6.8 \mathrm{a}$ & \\
\hline \multirow[b]{3}{*}{ Faba Bean } & 0 & $608.3 d$ & $1105.2 \mathrm{~d}$ & $86 c$ & $1.9 \mathrm{~d}$ & - & \\
\hline & 1 & $720 d$ & $1340 \mathrm{c}$ & $89 a$ & $2.0 \mathrm{c}$ & & \\
\hline & 5 & $1120 \mathrm{c}$ & $2100 \mathrm{~b}$ & $89 a$ & $3.0 \mathrm{~b}$ & & \\
\hline
\end{tabular}


The data present the mean number of yield and growth parameters of the experiments. Means having the same letters in a column were not significantly different at 5\% probability level.

Results of the investigation showed that the highest wheat yield at Guder and Ginchi was obtained when wheat was intercropped alternatively with faba bean at $5 \mathrm{t} \mathrm{ha}^{-1}$ fertilizer. Thus, the yield of sole wheat at control was lower compared with the yield obtained from wheat-legume intercropped systems at $5 \mathrm{t} \mathrm{ha}^{-1}$ organic fertilizer. This fact is supported by the research of Zahoor (2014), which indicated that organic fertilizer has the ability of increased yield production. Similarly, sole cropped possesses significant wheat yield at Guder and Ginchi sites, at highest organic fertilizer. But the lowest yield was obtained from sole wheat at both sites at the lower concentrations of organic fertilizer and control. This in accordance with the report of Ahmed Mam Rasul et al, 2015, shown that the sheep manure, cow manure and poultry manure were contributed for better yield production of wheat.

Even though all cropped system has been shown a better yield at high concentrations of organic fertilizer, intercropped systems did contributing in the production of the highest yield of wheat at both sites. This significant yield differences among both cultivars could be the result of arranges the organic treatments as sole and alternate cropping system. Similar report has been made by (Ahmed Mam Rasul et al, 2015).

\section{CONCLuSion}

From the obtained result, it can be concluded that, as concentration of organic fertilizer increased, there is an increment of yields among both cultivars at both Guder and Ginchi sites. But, the best yields of wheat were obtained from alternative intercropping at highest tested organic fertilizer at both sites. An arrangement of cropping systems with different concentrations of organic fertilizers has been proved to have an effect on yield and growth parameters of both wheat and faba bean. The tested level of organic fertilizer and cropping systems approach has very much useful as it increase the yield.

\section{ACKNOWLEDGEMENT}

The authors would like to acknowledge Ambo University for financial and technical supports for the study.

\section{REFERENCES}

[1] Ahmed Mam Rasul G., Ahmedand S.T. and Ahmed M.Q. (2015). Influence of Different Organic Fertilizers on Growth and Yield of Wheat. American-Eurasian J. Agric. \& Environ. Sci., 15: 1123-1126

[2] Eskandari H and Ghanbari A (2010) Effect of Different Planting Pattern of Wheat (Triticumaestivum) and Bean (Viciafaba) on Grain Yield, Dry Matte Production and Weed Biomass. Not Sci. Biol 2: 111-115

[3] GetachewAgegnehu, AmareGhizaw and Woldeyesus Sinebo (2008) Yield potential and Landuse Efficiency of Wheat and Faba Bean Mixed Iintercropping. Agron. Sustain. Dev. 28: 257-263

[4] Jensen, Erik Steen, Peoples, Mark B., Hauggaard-Nielsen, Henrik. (2010). Faba bean in cropping systems. Field crops research, 115: 203-216

[5] Muhammed A.S, Memon A.H, Baloch S.K, Osman K.A and Ali S.I. (2013). Effect of Bioorganic And Inorganic Fertilizers On the Growth and Yield of Wheat (Triticum aestivum L.) Persian Gulf Crop Protection 2: 15-24

[6] Tayebeh Abedi, Abass Alemzadeh and Seyed Abdolreza Kazemeini (2010). Effect of organic and inorganic fertilizers on grain yield and protein banding pattern of wheat. AJCS, 6:384-389

[7] Zahoor (2014). Influence of integrated use of chemical and organic fertilizers on yield and yield components of wheat. International Journal of Agriculture and Crop Sciences, 1: 21-25. 